\title{
PLASMA PROTEINS AND CRYOGLOBULINS IN ANARTHRITIC RHEUMATOID DISEASE*
}

\author{
BY \\ L. BAGRATUNI \\ Department of Clinical Biochemistry, Radcliffe Infirmary, Oxford
}

(RECEIVED FOR PUBLICATION NOVEMBER 8, 1956)

In previous communications (Bagratuni, 1953, 1956) a syndrome was described occurring in the middle-aged and elderly which was designated "anarthritic" rheumatoid disease. The main symptoms were severe aching of the muscles of the shoulder girdle and back, fever, and loss of weight, but without joint involvement. The erythrocyte sedimentation rate in active cases was exceptionally high, about $100 \mathrm{~mm}$./ hr (Westergren), and there were changes in the blood plasma proteins, the albumin being depressed, and the globulin and fibrinogen fractions raised.

The illness had an excellent prognosis, and was considered to be an anarthritic form of rheumatoid arthritis. In the present paper the detailed analysis of the plasma proteins by paper electrophoresis and chemical separation is described.

\section{Methods}

For electrophoretic fractionation barbitone buffer, $p \mathrm{H} 8.6$, was used and $0.02 \mathrm{ml}$. serum or heparinized plasma was applied to one end of a filter paper strip in an Evans Electroselenium electrophoresis apparatus. A current of $0.1 \mathrm{mAmp}$. per $\mathrm{cm}$. width of strip was passed for $18 \mathrm{hrs}$. The protein was then fixed to the strips by drying in an oven for $30 \mathrm{~min}$., developed in bromphenol blue for $10 \mathrm{~min}$., and repeatedly washed in 1 per cent. acetic acid. After drying, the strips were placed in a mixture of equal parts of household paraffin and bromobenzene for clearing, the air being extracted in a desiccating jar fitted with a vacuum pump. The intensity of the protein bands was measured with a photo-electric cell and plotted on graph paper, $1 \mathrm{~mm}$. of the filter paper strips corresponding to $1 \mathrm{~mm}$. points on the graph paper. The areas of the protein components were measured with a planimeter and expressed as percentages of the total. The chemical separation of the plasma proteins was done, in the case of albumin, by differential precipitation of the globulins with 22.5 per cent. sodium sulphate, and the protein content of the filtrate was estimated by the Biuret method. Fibrinogen was precipitated from oxalated

* This paper forms part of the D.M. thesis on anarthritic rheumatoid disease submitted to the University of Oxford. plasma with $2 \cdot 5$ per cent. calcium chloride and digested, and the nitrogen was estimated by the micro-Kjeldahl method. Total protein was estimated by the Biuret method, and globulin was derived by subtracting the albumin and fibrinogen from the total.

\section{Results}

Tables I and II (opposite) show the results for the electrophoretic and chemical methods.

The chemical separation in seventeen cases showed a fall in albumin from a normal mean of $4 \cdot 6$ to $3.5 \mathrm{~g} . / 100 \mathrm{ml}$, a rise in globulin from a normal mean of $2 \cdot 2$ to $3 \cdot 2 \mathrm{~g} . / 100 \mathrm{ml}$, a rise in fibrinogen from a normal mean of 275 to $731 \mathrm{mg} . / 100 \mathrm{ml}$., and a slight rise in total protein from a normal mean of 7 to $7 \cdot 3 \mathrm{~g} . / 100 \mathrm{ml}$.

In a group of four patients with minimal transient joint swelling (an intermediate stage between anarthritic rheumatoid disease and true rheumatoid arthritis), the changes were similar. The precipitation of globulins from serum with 22.5 per cent. sodium sulphate left some of the $\alpha_{1}$ globulin attached to the albumin. As the $\alpha_{1}$ globulin was raised in most cases, apart from normal subjects, the chemical albumin figure is deceptively high.

Electrophoretic analysis of the plasma and serum proteins in twelve patients with anarthritic rheumatoid disease and one with slight joint involvement allowed these findings to be examined in more detail.

The main changes were a fall in the albumin fraction from a normal mean of $60 \cdot 1$ to $42 \cdot 2$ per cent., a rise in $\alpha_{1}$ and $\alpha_{2}$ globulins from $3 \cdot 1$ to 6 per cent. and from $7 \cdot 3$ to $14 \cdot 5$ per cent. respectively, and a rise in fibrinogen from a normal mean of $10 \cdot 2$ to $15 \cdot 3$ per cent. The $\beta$ globulin was very slightly raised from a normal mean of $14 \cdot 4$ to $15 \cdot 4$ per cent. Two cases had a double $\beta$-band; on one the faster component corresponded to a cryoglobulin which gelled at room temperature.

Three cases with no joint symptoms had high $\gamma$ globulins ranging from $30 \cdot 0$ to $39 \cdot 5$ per cent., but 
TABLE I

ELECTROPHORETIC ANALYSIS OF NORMAL SERUM AND PLASMA, AND OF SERUM AND PLASMA FROM TWELVE CASES OF ANARTHRITIC RHEUMATOID DISEASE

\begin{tabular}{|c|c|c|c|c|c|c|}
\hline $\begin{array}{l}\text { Blood } \\
\text { Electrophoresis }\end{array}$ & Subjects & $\begin{array}{l}\text { No. of } \\
\text { Cases }\end{array}$ & Protein Fraction & $\begin{array}{c}\text { Mean } \\
\text { (per cent.) }\end{array}$ & $\begin{array}{l}\text { S.D. } \\
\pm\end{array}$ & $\begin{array}{c}\text { Range } \\
\text { (per cent.) }\end{array}$ \\
\hline \multirow{2}{*}{ Serum } & $\begin{array}{l}\text { Anarthritic } \\
\text { Rheumatoid } \\
\text { Disease (12)* }\end{array}$ & $\begin{array}{r}10 \\
2 \\
10 \\
12 \\
12 \\
12\end{array}$ & $\begin{array}{l}\text { Albumin } \\
\text { Albumin }+\alpha_{1} \text { globulin } \\
\alpha_{1} \text { Globulin } \\
\alpha_{2} \text { Globulin } \\
\beta \text { Globulin } \\
\gamma \text { Globulin }\end{array}$ & $\begin{array}{r}42 \cdot 2 \\
49 \cdot 4 \\
6 \cdot 0 \\
14 \cdot 5 \\
15 \cdot 4 \\
22 \cdot 0\end{array}$ & $\begin{array}{r}10 \cdot 2 \\
1 \cdot 3 \\
2 \cdot 7 \\
3 \cdot 8 \\
3 \cdot 4 \\
9 \cdot 5\end{array}$ & $\begin{array}{r}28 \cdot 5-66 \cdot 1 \\
48 \cdot 2-50 \cdot 6 \\
1 \cdot 1-10 \cdot 9 \\
10 \cdot 5-20 \cdot 5 \\
8 \cdot 1-21 \cdot 4 \\
4 \cdot 3-33 \cdot 4\end{array}$ \\
\hline & Normal (7) & $\begin{array}{l}6 \\
1 \\
6 \\
7 \\
7 \\
7\end{array}$ & $\begin{array}{l}\text { Albumin } \\
\text { Albumin }+\alpha_{1} \text { globulin } \\
\alpha_{1} \text { Globulin } \\
\alpha_{2} \text { Globulin } \\
\beta \text { Globulin } \\
\gamma \text { Globulin }\end{array}$ & $\begin{array}{r}60 \cdot 1 \\
53 \cdot 6 \\
3 \cdot 1 \\
7 \cdot 3 \\
14 \cdot 4 \\
22 \cdot 0\end{array}$ & $\begin{array}{r}11 \cdot 0 \\
1 \cdot 6 \\
0 \cdot 8 \\
1 \cdot 0 \\
3 \cdot 5 \\
5 \cdot 4\end{array}$ & $\begin{array}{r}52 \cdot 7-67 \cdot 4 \\
45 \cdot 6-59 \cdot 1 \\
2 \cdot 7-3 \cdot 4 \\
6 \cdot 5-8 \cdot 7 \\
12 \cdot 2-21 \cdot 0 \\
11 \cdot 8-28 \cdot 1\end{array}$ \\
\hline \multirow{2}{*}{ Plasma } & $\begin{array}{l}\text { Anarthritic } \\
\text { Rheumatoid } \\
\text { Disease (9) }\end{array}$ & $\begin{array}{l}5 \\
4 \\
5 \\
9 \\
7 \\
2 \\
5 \\
2 \\
7\end{array}$ & $\begin{array}{l}\text { Albumin } \\
\text { Albumin }+\alpha_{1} \text { globulin } \\
\alpha_{1} \text { Globulin } \\
x_{2} \text { Globulin } \\
\beta \text { Globulin } \\
\beta \text { Globulin }+ \text { fibrinogen } \\
\text { Fibrinogen } \\
\text { Fibrinogen }+\gamma \text { globulin } \\
\gamma \text { Globulin }\end{array}$ & $\begin{array}{r}34 \cdot 8 \\
45 \cdot 4 \\
5 \cdot 4 \\
12 \cdot 4 \\
11 \cdot 7 \\
31 \cdot 0 \\
15 \cdot 3 \\
27 \cdot 1 \\
18 \cdot 8\end{array}$ & $\begin{array}{r}8 \cdot 7 \\
15 \cdot 3 \\
2 \cdot 1 \\
5 \cdot 2 \\
3 \cdot 9 \\
0 \cdot 2 \\
4 \cdot 4 \\
4 \cdot 6 \\
8 \cdot 9\end{array}$ & $\begin{array}{r}26 \cdot 7-48 \cdot 9 \\
33 \cdot 9-67 \cdot 3 \\
2 \cdot 0-7 \cdot 4 \\
7 \cdot 6-22 \cdot 0 \\
5 \cdot 4-16 \cdot 9 \\
30 \cdot 9-31 \cdot 3 \\
9 \cdot 0-20 \cdot 1 \\
22 \cdot 5-31 \cdot 7 \\
7 \cdot 4-29 \cdot 3\end{array}$ \\
\hline & Normal (5) & $\begin{array}{l}5 \\
5 \\
5 \\
5 \\
5 \\
5\end{array}$ & $\begin{array}{l}\text { Albumin } \\
\alpha_{1} \text { Globulin } \\
\alpha_{2} \text { Globulin } \\
\beta \text { Globulin } \\
\text { Fibrinogen } \\
\gamma \text { Globulin }\end{array}$ & $\begin{array}{r}50 \cdot 6 \\
2 \cdot 6 \\
7 \cdot 7 \\
12 \cdot 2 \\
10 \cdot 2 \\
15 \cdot 5\end{array}$ & $\begin{array}{l}4 \cdot 0 \\
0 \cdot 4 \\
2 \cdot 7 \\
2 \cdot 2 \\
2 \cdot 3 \\
1 \cdot 6\end{array}$ & $\begin{array}{r}46 \cdot 5-55 \cdot 5 \\
2 \cdot 2-3 \cdot 2 \\
5 \cdot 2-12 \cdot 3 \\
9 \cdot 2-14 \cdot 2 \\
7 \cdot 8-12 \cdot 4 \\
13 \cdot 9-17 \cdot 4\end{array}$ \\
\hline
\end{tabular}

* Two male (Age range 59 to 75 yrs, average 67). Ten female (Age range 55 to 85 yrs, average 68).

TABLE II

ERYTHROCYTE SEDIMENTATION RATE AND CHEMICAL ANALYSIS OF PLASMA PROTEINS IN ANARTHRITIC RHEUMATOID DISEASE

\begin{tabular}{|c|c|c|c|c|c|}
\hline Estimation & $\begin{array}{c}\text { Erythrocyte } \\
\text { Sedimentation } \\
\text { Rate } \\
\text { (mm./hr, Westergren) }\end{array}$ & $\underset{\text { (g. per cent.) }}{\text { Albumin }}$ & $\begin{array}{c}\text { Globulin } \\
\text { (g. per cent.) }\end{array}$ & $\begin{array}{c}\text { Fibrinogen } \\
\text { (mg. per cent.) }\end{array}$ & $\begin{array}{l}\text { Total Protein } \\
\text { (g. per cent.) }\end{array}$ \\
\hline No. of Cases & 17 & 17 & 17 & 13 & 17 \\
\hline Mean & 100 & $3 \cdot 5$ & $3 \cdot 2$ & 731 & $7 \cdot 3$ \\
\hline S.D. \pm & 22 & $0 \cdot 3$ & $0 \cdot 7$ & 236 & 0.9 \\
\hline Range & $25-148$ & $2 \cdot 9-4 \cdot 2$ & $2 \cdot 3-5 \cdot 2$ & $260-1,240$ & $5 \cdot 8-9 \cdot 0$ \\
\hline
\end{tabular}

the average was normal. Two of the patients with high $\gamma$ globulin had small amounts of cryoglobulin. One patient with slight joint involvement, in whom protein electrophoresis was done, also had a raised $\gamma$ globulin of $28 \cdot 7$ per cent. The blood plasma electrophoresis showed a slight rise in the $\gamma$ globulin as compared with the serum, probably due to contamination with migrating fibrinogen.

The characteristic decrease in albumin and increase in the $\alpha_{1}$ and $\alpha_{2}$ globulin bands, and the pattern corresponding to these changes, are shown in Figs 1 and 2 (overleaf), where they are compared with results in normal subjects.

\section{Discussion}

The findings on electrophoretic analysis of the plasma proteins are on the whole non-specific for the collagen diseases, as the proportion of change in the fractions depends on the severity and duration of the illness. Nevertheless, changes do occur, which in conjunction with the clinical findings may help to establish a diagnosis. As the syndrome here described resembles early rheumatoid arthritis, and to a lesser extent rheumatic fever and the other collagen diseases in their prodromal stages, the findings will be discussed in relation to all these conditions. 


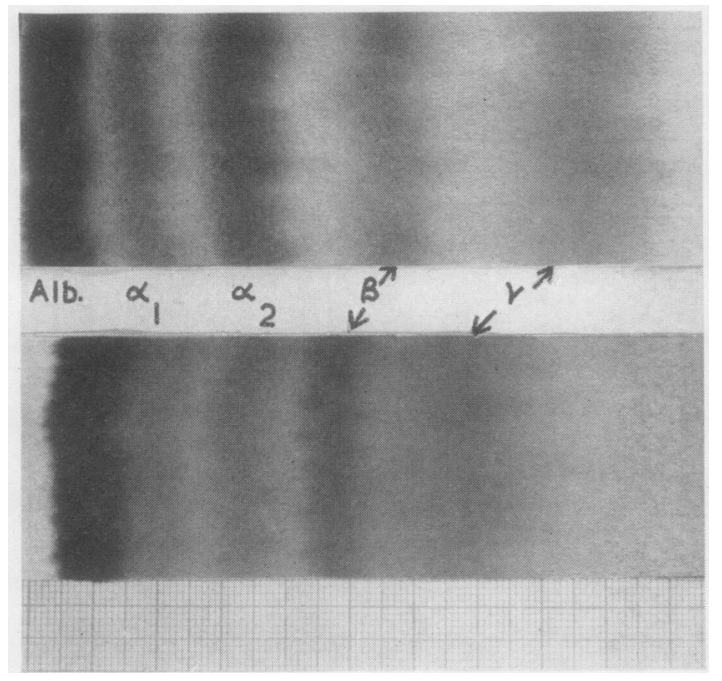

Fig. 1.-Serum of anarthritic rheumatoid disease, showing pronounced $\alpha_{1}$ and $\alpha_{2}$ globulin bands (above) compared with normal serum (below). $\beta$ and $\gamma$ globulin are within normal limits in both cases.

Ropes, Perlmann, Kaufman, and Bauer (1954) found the $\alpha$ globulins higher in rheumatoid arthritis than in systemic lupus erythematosus, and the $\gamma$ globulin in the former rose later than in the latter. The $\alpha$ and $\gamma$ globulin fractions were similarly raised in cases of rheumatoid arthritis described by Trutschel and Frölich (1953) with an occasional slight rise in the $\beta$ fraction, as in the present series. Hunt and Trew (1954) reported similar findings, and Lush, Crowley, Fletcher, and Buchan (1951) found these blood changes reflected in the depressed albumin and raised globulin of the cerebrospinal fluid in rheumatoid arthritis. Lever, Schultz, and Hurley (1951) described slight increases in the $\alpha$ and $\beta$ fractions and larger increases in the $\gamma$ fraction in systemic lupus erythematosus. As the initial symptoms of anarthritic rheumatoid disease are very similar to those of early systemic lupus erythematosus, it is interesting to note that in the former there is rarely a rise in the globulin whereas this rise is common in the latter.

In rheumatic fever, a condition again very similar in its early manifestations to anarthritic rheumatoid disease, Wilson and Lubschez (1948) found raised $\alpha_{1}$ and $\alpha_{2}$ globulin fractions, but they considered that the $\gamma$ globulin was within normal limits unless there had been antecedent infection. Ropes and others (1954) similarly thought that the $\gamma$ globulin was raised in this condition in the presence of antecedent infection or organ involvement, and in the late stages of the disease. Jackson, Kelly, Smith, Wang, and Routh (1953), however, invariably found a raised $\gamma$ globulin in rheumatic fever.

In the present series, if the two cases of raised $\gamma_{0}$ globulin with cryoglobulinaemia are excluded, only응 one patient out of twelve with anarthritic rheumatoid disease had a raised $\gamma$ globulin fraction. These findings are similar to those in early rheumatoid. arthritis and uncomplicated rheumatic fever, before

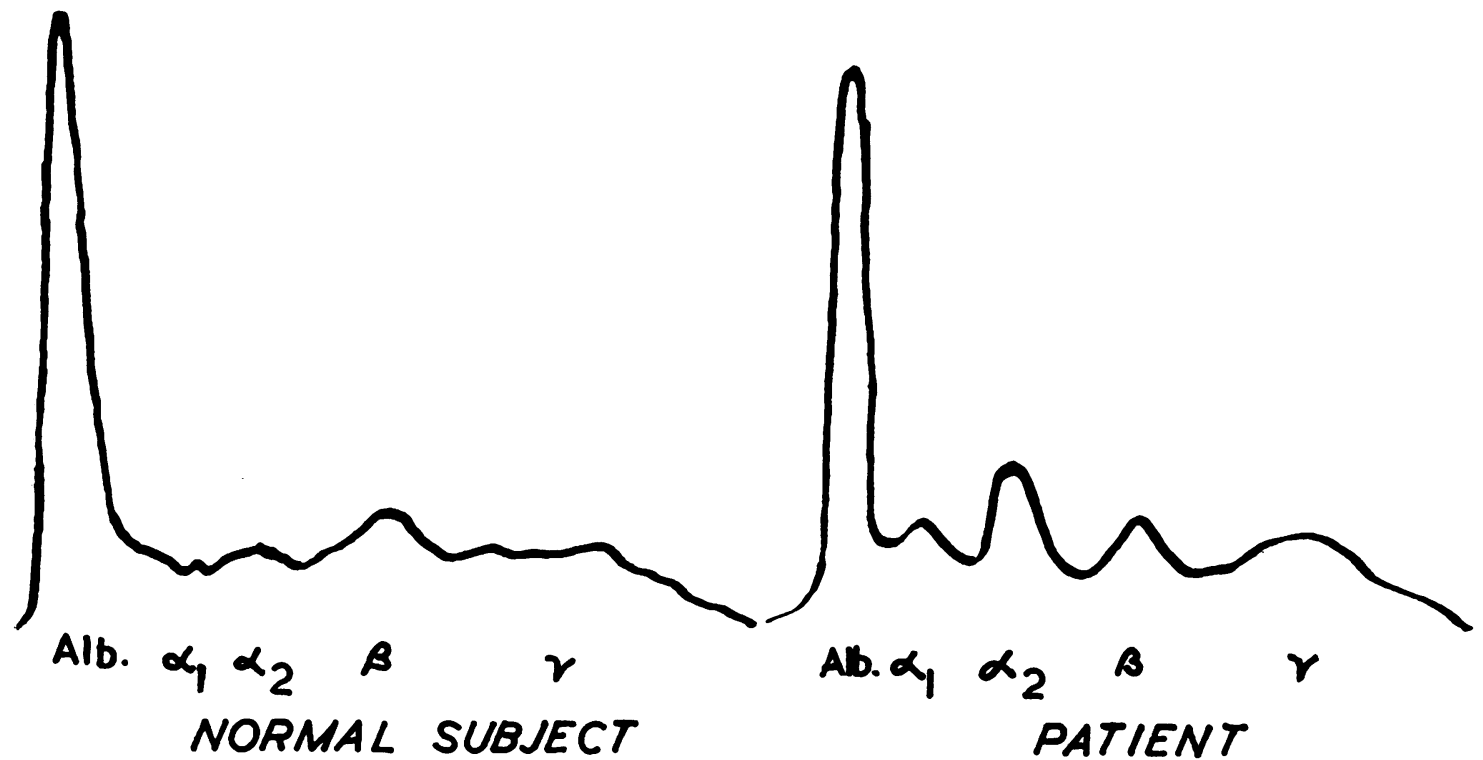

Fig. 2.-Electrophoretic pattern of Fig. 1, showing decrease in albumin and increase in $\alpha_{1}$ and $\alpha_{2}$ globulin fractions in a patient with anarthritic rheumatoid disease (Right) and a normal subject (Left). 
organ involvement occurs. The patients with anarthritic rheumatoid disease, however, had often been ill for months without a rise in the $\gamma$ globulin, whereas it is rare for the $\gamma$ globulin to remain normal for months in the other two conditions. The $\alpha$ globulins are recognized as responding to inflammation and early tissue damage, whereas the $\gamma$ globulin is an antibody reaction to foreign protein or more extensive tissue damage (Lever and others, 1951). It follows that, in anarthritic rheumatoid disease, early rheumatoid arthritis, and rheumatic fever, before the stage of organ involvement is reached and during early inflammation, only the $\alpha$ globulin fractions will be raised. Later, as the organs become more extensively involved, with greater tissue breakdown, so the $\gamma$ globulin will rise. The characteristic feature of anarthritic rheumatoid disease is the absence of gross organ or joint involvement in the presence of a general systemic disturbance, hence the rise in the $a$ globulins but not in $\gamma$ globulin. This confirms the benign nature and good prognosis of the condition.

In one case of transient joint involvement, the $\gamma$ globulin was raised to $28 \cdot 7$ per cent. on electrophoresis. Other conditions, which resemble anarthritic rheumatoid disease in their early stages and in which the $a_{1}, a_{2}$, and $\gamma$ globulins may be high, include ankylosing spondylitis (Hunt and Trew, 1954), periarteritis nodosum (Darmady, Griffiths, Spencer, Mattingly, Stranak, and de Wardener, 1955), Sjögren's syndrome (McLenachan and Tonks, 1955), scleroderma (Lever and others, 1951), erythema nodosum (Malmros and Blix, 1946), and Hodgkin's disease (Arends, Coonrad, and Rundles, 1934). In dermatomyositis, the $\gamma$ globulin may be within normal limits or only slightly raised (Lever and others, 1951; Ropes and others, 1954). All these diseases, however, develop a characteristic clinical pattern.

Wallis (1950) found a T-fraction occurring in rheumatoid arthritis between the $\beta$ and $\gamma$ globulin bands. In the present series a double $\beta$-band was found in two cases. In one the faster moving component corresponded with a cryoglobulin; in the other the slower component may well have been this T-band.

The increase in the $a$ globulins found in collagen disease in response to inflammation is related to a rise in the polysaccharide-rich mucoproteins (Badin and Glyn, 1954; Fantuzzi and Neuhaus, 1955; Markham, 1955). Blood mucoproteins may also be raised in a variety of other conditions (Sachs, Cady, and Ross, 1954), and the mucoprotein may be associated with different fractions: with albumin in cancer, for example, and with globulin in myeloma.
Wilhelm, Miles, and Mackay, (1955) consider that it is the $\alpha_{2}$ fraction which causes increased capillary permeability in hyperglobulinaemia, and is more potent than histamine in this respect.

In the collagen diseases a raised fibrinogen fraction is common; it has been reported in rheumatoid arthritis (Davis, 1936; Malmros and Blix, 1946; Hunt and Trew, 1954), rheumatic fever (Malmros and Blix, 1946; Jackson and others, 1953), systemic lupus erythematosus (Ropes and others, 1954), and dermatomyositis (Ropes and others, 1954). Usually the upper level is in the region of $600-700 \mathrm{mg} . / 100 \mathrm{ml}$. It is characteristic of anarthritic rheumatoid disease that the fibrinogen level may be nearer $1,000 \mathrm{mg}$./ $100 \mathrm{ml}$. or over, as in three cases in the present series. Moreover, this level may be present in a patient who is ambulant and not obviously unduly ill. The greatly raised erythrocyte sedimentation rate is related both to the high fibrinogen level and to the alteration in the albumin/globulin ratio, although the former factor appears to be the more important.

Exceptionally, Aldred-Brown and Munro (1935) found only minimal changes in the fibrinogen level of patients with rheumatoid arthritis, and McLenachan and Tonks (1955) found normal levels in fifteen cases of Sjögren's syndrome. In the only case of Sjögren's syndrome in the present series it was impossible to estimate the fibrinogen level owing to the presence of cryoglobulin. Cryoglobulins are now recognized to be fairly common in diseases involving an alteration in the plasma proteins (Mackay, Eriksen, Motulsky, and Volwiler, 1956). Holmberg and Grönwall (1942) were the first to describe a cryoglobulin in rheumatoid arthritis, and they showed it to lie between the $\beta$ and $\gamma$ globulin bands. There were three cases of cryoglobulinaemia in the present series (Table III, overleaf).

In Cases 1 and 3 the abnormal protein appeared to occur in the $\gamma$ globulin fraction, although there was insufficient for detailed analysis. In the second case it formed the faster moving component of the double $\beta$-band, similar to that of Holmberg and Grönwall, and it gelled at room temperature. In Case 2 separation of the cryoglobulin by centrifuging in a refrigerated centrifuge yielded $0.6 \mathrm{~g}$. protein per $100 \mathrm{ml}$. (Figs 3 and 4, overleaf).

It is interesting to note that in two of the three cases of cryoglobulinaemia in which sternal puncture was done, both had 5 per cent. plasma cells, the upper limit of normal. If plasma cells are responsible for the production of some of the globulins, then the stimulus producing this plenitude of plasma cells may well be responsible for the production of abnormal protein from the cells. This is borne out by the frequent occurrence of cryoglobulins in cases 
ELECTROPHORETIC AND CHEMICAL ANALYSIS OF BLOOD SERUM AND PLASMA PROTEINS IN THREE CASES OF CRYOGLOBULINAEMIA WITH ANARTHRITIC RHEUMATOID DISEASE

\begin{tabular}{|c|c|c|c|c|c|}
\hline Case No. & & & 1 & 2 & 3 \\
\hline Sex & & & $\mathbf{F}$ & $\mathbf{F}$ & $\mathrm{F}$ \\
\hline Age & & & 60 & 56 & 67 \\
\hline \multirow{13}{*}{ Analysis } & \multirow{7}{*}{$\begin{array}{l}\text { Electrophoretic } \\
\text { (per cent.) }\end{array}$} & Albumin & $32 \cdot 6$ & - & - \\
\hline & & Albumin $+\alpha_{1}$ Globulin & 一 & $48 \cdot 2$ & $33 \cdot 9$ \\
\hline & & $\alpha_{1}$ Globulin & $6 \cdot 3$ & - & - \\
\hline & & $\alpha_{2}$ Globulin & $16 \cdot 8$ & $13 \cdot 2$ & $9 \cdot 1$ \\
\hline & & $\beta$ Globulin & $14 \cdot 2$ & $\begin{array}{llll}\beta_{1} & 15.6 & \beta_{2} & 5.4\end{array}$ & $13 \cdot 3$ \\
\hline & & Fibrinogen & (Serum) & (Serum) & $18 \cdot 9$ \\
\hline & & $\gamma$ Globulin & $30 \cdot 0$ & $18 \cdot 0$ & $24 \cdot 8$ \\
\hline & \multirow{6}{*}{$\begin{array}{l}\text { Chemical } \\
\text { (g. per cent.) }\end{array}$} & $\begin{array}{l}\text { Erythrocyte } \\
\text { Sedimentation } \\
\text { Rate } \\
\text { (mm./hr, Westergren) }\end{array}$ & 125 & 72 & 112 \\
\hline & & Albumin (g.) & $3 \cdot 5$ & $4 \cdot 2$ & $3 \cdot 8$ \\
\hline & & Globulin (g.) & $4 \cdot 1$ & $2 \cdot 3$ & $5 \cdot 2$ \\
\hline & & Fibrinogen (mg.) & 840 & Impossible & (Serum) \\
\hline & & Total (g.) & $8 \cdot 4$ & $7 \cdot 2$ & $9 \cdot 0$ \\
\hline & & Cryoglobulin & Insufficient & $0.6 \mathrm{~g}$ & Insufficient \\
\hline
\end{tabular}

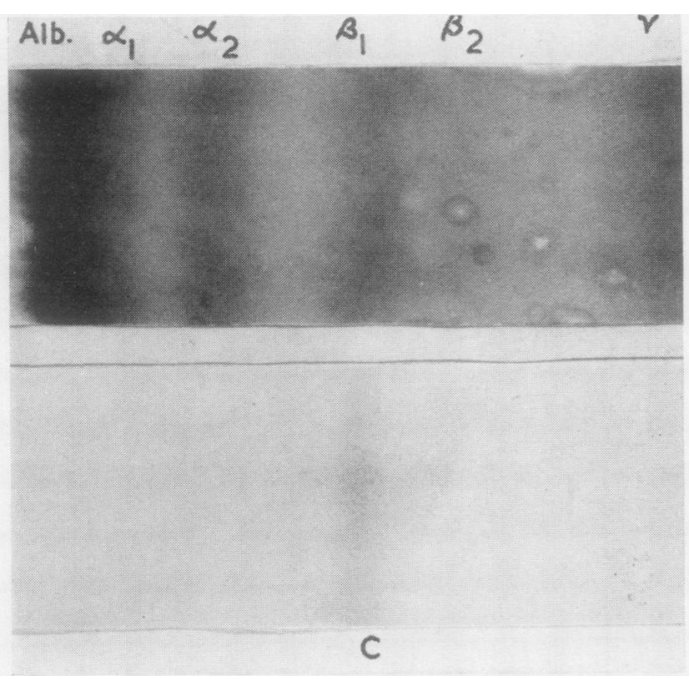

Fig. 3.-Electrophoresis of serum (above) and of cryoglobulin precipitate $(\mathrm{C})$ re-dissolved in normal saline (below). The mobility of the cryoglobulin is the same as that of the $\beta_{1}$ globulin.

of myelomatosis where both plasma cells and globulins are present in excessive amounts.

\section{Conclusion}

The differential diagnosis of anarthritic rheumatoid disease has already been discussed (Bagratuni,
Fig. 4.-Electrophoretic curves of Fig. 3. The $\alpha_{1}$ globulin is merged into the albumin curve.

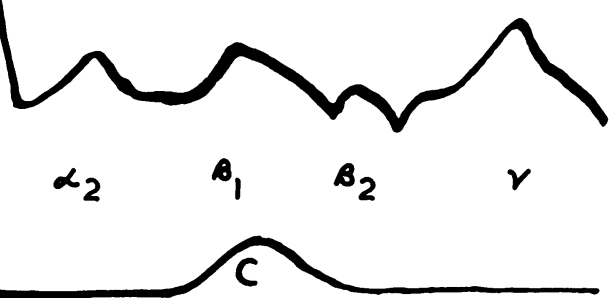

1953, 1956). In the afebrile manifestations of this disease the usual diagnosis is "fibrositis", fibromyalgia, or some such descriptive term. Since the time of Gowers (1904), "fibrositis" has been considered to be a mild, benign condition not involving systemic change. Thus Slocumb (1936) found a 
raised erythrocyte sedimentation rate in only 11 per cent. of his cases, and in these not above $32 \mathrm{~mm}$./hr. Race (1940) similarly found a normal erythrocyte sedimentation rate in "fibrositis", apart from a few cases which resembled rheumatoid arthritis. Johnson (1955) considered "fibrositis" to be a noninflammatory condition.

Much depends on the stage at which such patients are seen. In the early and late stages of anarthritic rheumatoid disease, when activity is only slight, the erythrocyte sedimentation rate and plasma protein changes are minimal, although the pains in the muscles may be quite severe. In the more active cases, with or without fever, blood changes are present but there is little increase in the severity of the symptoms.

It is not intended to suggest here that all cases of so-called "fibrositis" have systemic changes, but in many these diffuse aches are a manifestation of anarthritic rheumatoid disease, which I consider to be a forme fruste of rheumatoid arthritis. Serial estimations of the blood changes in the patients studied have shown variations from normality to gross abnormality even in those remaining afebrile. The plasma proteins in anarthritic rheumatoid disease thus reflect the generalized systemic disturbance by a rise in the fibrinogen level and in the $\alpha_{1}$ and $\alpha_{2}$ globulins, and absence of gross tissue destruction is confirmed by the fact that the $\gamma$ globulin usually remains within normal limits. These observations are in keeping with the clinical finding of an excellent prognosis.

\section{Summary}

Electrophoretic and chemical blood plasma and serum protein analysis in seventeen cases of anarthritic rheumatoid disease showed a lowered albumin fraction and $\alpha_{1}$ and $\alpha_{2}$ globulins raised to twice the normal level.

The plasma fibrinogen level was very high in active cases (1,000 mg. per cent. or over in three instances). It was the main cause of the greatly accelerated erythrocyte sedimentation rate.

Three cases had cryoglobulinaemia: in two the abnormal protein was apparently associated with the $\gamma$ globulin, and in one with the slower component of a double $\beta$-band.

The average $\gamma$ globulin level was within normal limits, and the $\beta$ globulin a fraction above normal.

These results are discussed in relation to the electrophoretic findings in other collagen diseases, and it is suggested that the good prognosis of anarthritic rheumatoid disease is in part due to lack of extensive tissue destruction, as reflected clinically and in the normal $\gamma$ globulin level.

I am indebted to Professor L. J. Witts, Dr. F. G. Hobson, and Dr. A. M. Cooke for allowing me access to their patients.

I am especially grateful to Dr. A. M. Cooke and Mr. J. R. P. O'Brien for reading through this paper, and for their advice. I must also thank the Biochemistry Department for carrying out some of the routine chemical plasma protein estimations.

\section{REFERENCES}

Aldred-Brown, G. R. P., and Munro, J. M. H. (1935). Quart. J. Med. 28 (n.s. 4), 269.

Arends, T., Coonrad, E. V., and Rundles, R. W. (1934). Amer. J Med., 16, 833 .

Badin, J., and Glyn, J. (1954). Proc. Soc. exp. Biol. (N.Y.), 86, 150. Bagratuni, L. (1953). Annals of the Rheumatic Diseases, 12, 98. (1956). Lancet, 2, 694.

Darmady, E. M., Griffiths, W. J., Spencer, H., Mattingly, D., Stranak, F., and de Wardener, H. E. (1955). Lancet, 1, 378.

Davis, J.' S. (1936). J. lab. clin. Med., 21, 478.

Fantuzzi, B., and Neuhaus, C. (1955). Minerva pediat. (Torino), 7, 478 .

Gowers, W. R. (1904). Brit. med. J., 1, 117.

Holmberg, C. G., and Grönwall, A. (1942). Hoppe-Seyl. Z. physiol. Chem., 273, 199.

Hunt, T. E., and Trew, J. A. (1954). Annals of the Rheumatic Diseases, 13, 201.

Jackson, R. L., Kelly, H. G., Smith, E. K., Wang, P., and Routh, J. I. (1953). Amer. J. Dis. Child., 86, 403.

Johnson, D. A. (1955). J. Amer. med. Ass., 159, 1507.

Lever, W. F., Schultz, E. L., and Hurley, N. A. (1951). A.M.A. Arch. Derm. Syph., 63,702.

Lush, B., Crowley, M. F., Fletcher, E., and Buchan, J. F. (1951). Annals of the Rheumatic Diseases, 10, 153.

Mackay, I. R., Eriksen, N., Motulsky, A. G., and Volwiler, W. (1956). Amer. J. med., $20,564$.

Malmros, H., and Blix, G. (1946). Acta med. scand., Suppl. 170, p. 280 .

Markham, R. L. (1955). Lancet, 2, 145.

Markham, R. L. (1955). Lancet, 2, 145.

Ropes, M. W., Perlmann, G. E., Kaufman, D., and Bauer, W. (1954). J. clin. Invest., 33, 311 .

Race, J. (1940). Annals of the Rheumatic Diseases, 2, 127.

Sachs, B. A., Cady, P., and Ross, G. (1954). Amer. J. Med., 17, 662.

Slocumb, C. H. (1936). J. Lab. clin. Med., 22, 56.

Trutschel, W., and Frölich, J. (1953). Münch. med.
Wallis, A. D. (1950). Ann. intern. Med., 32, 63.

Wilhelm, D. L., Miles, A. A., and Mackay, M. E. (1955). Brit. J. exp. Path., 36, 82.

Wilson, M. G., and Lubschez, R. (1948). Pediatrics, 2, 577.

Les protéines du plasma et les cryoglobulines dans la maladie rhumatismale anarthritique

RÉSUMÉ

Dans 17 cas de maladie rhumatismale anarthritique, les analyses électrophorétiques et chimiques du plasma sanguin et de la protéine du sérum, ont montré la fraction albumine diminuée et les globulines $\alpha_{1}$ et $\alpha_{2}$ augmentées jusqu'à deux fois leur chiffre normal.

Le chiffre de fibrinogène du plasma était très élevé dans les cas évolutifs (1000 mg./pour cent ou plus, dans trois d'entre eux). C'était là la cause principale d'une sédimentation erythrocytaire considérablement acclérée.

Trois cas présentaient de la cryoglobulinaemie; chez deux d'entre eux, la protéine anormale était apparemment associée à la globuline $\gamma$ et chez l'un, avec le constituant plus lent d'une double bande $\beta$.

Le chiffre moyen de globuline $\gamma$ se tenait dans des limites normales et celui de globuline $\beta$ un peu au-dessus de la normale.

On discute ces résultats en relation avec les résultats 
électrophorétiques dans d'autres maladies collagènes et on suggère que le bon pronostic de la maladie rhumatismale anarthritique est partiellement dû à l'absence de destruction extensive des tissus, comme le montre l'état clinique et le chiffre normal de globuline $\gamma$.

\section{Las proteinas del plasma y las crioglobulinas en la enfermedad reumática anartritica}

\section{Sumario}

En 17 casos de enfermedad reumática anartrítica el análisis electroforético y químico del plasma sanguíneo y de la proteina sérica mostraron una diminución de la fracción albumina y una aumentacion, hasta el doble de la cifra normal, de las globulinas $\alpha_{1}$ y $\alpha_{2}$.
Las cifras del fibrinógeno del plasma fueron muy altas en los casos evolutivos $(1.000 \mathrm{mg}$ por ciento o más en tres casos). Esto fué la causa de la gran aceleratión de la sedimentación eritrocitaria.

Tres casos presentaron crioglobulinemia; en dos de estos, la proteina normal viose aparentemente asociada a la globulina $\gamma \mathrm{y}$, en uno, con el componente màs lento de una doble faja $\beta$.

La cifra media de globulina $\gamma$ se mantuvo dentro de los límites normales y la de globulina $\beta$ algo encima de lo normal.

Estos resultados se discuten en relación a los hallazgos electroforéticos en otras enfermedades colágenas y se sugiere que la buena prognosis de la enfermedad reumática anartrítica se debe en parte a la ausencia de destrucción extensa du los tejidos, lo que se refleja en el estado clínico y en las cifras normales de globulina $\gamma$. 